\title{
Local Environmental Legislation and Employment Growth: Evidence from Chinese Manufacturing Firms
}

Lei Wen ( $\nabla$ wenlei@cueb.edu.cn )

Capital University of Economics and Business

Hongbing Li

Beijing University of Posts and Telecommunications

Xueying Bian

Beijing University of Posts and Telecommunications

\section{Research Article}

Keywords:

Posted Date: February 7th, 2022

DOI: https://doi.org/10.21203/rs.3.rs-1214144/v1

License: (c) (i) This work is licensed under a Creative Commons Attribution 4.0 International License.

Read Full License 


\section{Title page}

2 Title: Local Environmental Legislation and Employment Growth: Evidence from

3 Chinese Manufacturing Firms

4

5 Corresponding Author: Associate Professor Hongbing Li

6 Corresponding Author's Institution: Beijing University of Posts and

7 Telecommunications

8 E-mail addresses: hongbingli@bupt.edu.cn;

9 Telephone numbers: $(+86) 18810343428$

10 Full postal address: No.10 Xitucheng Road, College of Economics and Management,

11 Beijing University of Posts and Telecommunications, Beijing, 100876, P.R. China.

13 First Author: Lei Wen

14 Order of Authors: Lei Wen ${ }^{\mathrm{a}}$, Hongbing $\mathrm{Li}^{\mathrm{b}}$, Xueying Bian ${ }^{\mathrm{b}}$

$16{ }^{a}$ College of Economics, Capital University of Economics and Business, No.121 17 Zhangjiakou Road, Beijing, 100070, P.R. China.

18 b College of Economics and Management, Beijing University of Posts and 19 Telecommunications, No.10 Xitucheng Road, Beijing, 100876, P.R. China.

21 - The email addresses of all authors:

22 PhD in Economics \& Assistant Professor, Lei Wen, wenlei@cueb.edu.cn PhD in Economics \& Associate Professor, Hongbing Li, hongbingli@ bupt.edu.cn PhD in Economics \& Assistant Professor, Xueying Bian, xybian.2021@bupt.edu.cn 


\section{Local Environmental Legislation and Employment Growth:} Evidence from Chinese Manufacturing Firms

Abstract: Using the data on provincial environmental legislation and Chinese manufacturing firms during 1998-2013, this paper empirically tests the impact of provincial environmental legislation on the firms' employment growth with a difference-in-difference (DID) model. The results show that after the implementation of environmental legislation, the employment growth of regulated manufacturing firms decreases significantly by $3.07 \%$, and this result is robust to alternative tests. The empirical analysis also indicates that local environmental legislation reduces employment growth mainly via the mediating mechanism of the firm's entry and exit, export and innovation. Moreover, we find the local environmental legislation has heterogeneous impacts on employment growth in different industries and different regions, and the estimated effect is more obvious in highpollution industries and areas with strong enforcement. This paper helps assess the impact of Chinese environmental policy on employment and provides important policy implications for improving existing laws and regulations to achieve higher social welfare.

Key Words: environmental legislation; employment growth; employment reallocation; regional law enforcement intensity; Difference in Difference method 


\section{Introduction}

Since the Reform and Opening Up in 1978, China's economy has maintained around an average $10 \%$ annual GDP growth rate during the process of urbanization and industrialization. China's economic growth is widely viewed as the extensive economic growth mode at the cost of environmental pollution under the loose environmental regulations, leading to the trade-off between "green water and green mountains" and "gold and silver mountains". According to the State of China's Ecology and Environment in 2017, 70.7\% of the 338 cities failed to meet the air quality standards. There were 2,311 days with heavy pollution and 802 days with serious pollution. Among the days of severe pollution, the days with PM2.5 as the primary pollutant accounted for $74.2 \%$. In addition, the water was also highly polluted, with $32.1 \%$ of the surface water quality above III class and $8.3 \%$ of the surface water has become inferior $\mathrm{V}$ class. Such serious environmental issues could affect individual's health and normal life, and it will also hinder the country's economic development in the long run. In such situation, the implementation of stricter environmental regulations is of great significance to improve the quality of the ecological environment and promote the sustainable development of China's economy. Among all environmental regulations, environmental legislation, as a typical method of command-and-control environmental regulation, is the most direct and widely used in China. Environmental protection clause was first included in China's Constitution in 1978. By the end of 2018, China's central government has enacted more than 30 laws, including the Environmental Protection Law, the Law on Promoting Circular Economy, etc., accounting for more than one-tenth of the total legislations of the National People's Congress and its Standing Committee. The environmental administration department under the State Council has also formulated more than 130 administrative regulations on environmental protection, including the Regulations on Nature Reserves and the Regulations on Wildlife Protection, ect., and nearly 2,000 national environmental standards, forming a relatively complete environmental legal system.

However, the strict environmental regulation, aiming at protecting ecological environment and saving natural resources, could have a negative impact on the economy in the short term, especially on employment. According to the existing literature, the effect of environmental regulation on employment has not reached a unanimous conclusion yet. Greenstone (2002) points out that the amendments to the Clean Air Act in the United States reduced nearly 600,000 jobs in areas that failed to meet the standard. Kahn and Mansur (2013) find that in certain industries such as credit intermediaries and raw materials metals in the United States, the employment elasticity of energy prices was significantly negative. The study of Gray et al. (2014) shows that the "agglomeration rule management" (CRM) of the US Environmental Protection Agency had a slightly negative effect on employment in the pulp and paper industry, but the effect was not significant. Different from the above findings, Berman and Bui (2001) discover that air quality agreements in the United States did not reduce employment but had a slight promotion effect. In addition, some scholars believe that the relationship between environmental regulation and employment is uncertain. The diversified effects may result from the difference in industry energy intensity (Aldy and Pizer, 2015), the 
difference in labor force proficiency (Sen and Acharyya, 2012), or the difference in ecological innovation (Horbach and Rennings, 2013).

In recent years, with the environmental problems becoming more and more prominent, more researchers pay attention to China's context from both macro perspective (Liu et al., 2018) and micro levels (Liu et al., 2017). China's legislative process is vastly different from that in western economies. In China, the formulation of laws and regulations is mainly done from top to bottom, that is, the central government will first determine the basic target and general framework of the law, then the central government's legislative principles need to be implemented through local government legislation. In terms of the legislation related to environmental protection, China is different from western countries in at least two perspectives. First, in China, the central government first sets the overall goal of environmental protection, then the local governments share the overall goal together. The environmental protection goal of the central government will be shared by all provinces, and the goal proposed by all provinces will be shared by their subordinate districts and counties. ${ }^{1}$ Second, for the emission standard of some specific pollutants, China's local government often sets stricter standards than the central government. ${ }^{2}$ As a result, the local government's environmental legislation in China usually has a more direct and significant impact on firms' production and business decision. Furthermore, labor unions in China are very different compared with those in the western countries. They must support the centralized and unified leadership of the CPC (Communist Party of China) and maintain a high degree of consistency with the CPC Central Committee on its political stance, direction, principles, and path. ${ }^{3}$ This dependence may cause China's labor unions to play a different role in protecting workers' interests. To sum up, the difference in environmental legislative procedures and labor unions between China and western economies may lead to different effects of environmental regulation on labor market. Thus, exploring how environmental regulation affects labor demand in China requires empirical investigation based on regional legislation instead of central policy.

Due to the complexity of environmental regulations and the limits of data availability, the measurement on the intensity of environmental regulation is still questionable. The related studies use the cost of reducing pollution (Levinson,1996; Keller and Levinson,2003), the pollution or energy consumption (Naughton,2014; Cole and Elliot,2003), the investment on dealing with pollution (Shadbegian and Gray,2009) and government's environmental regulations (Javorcik and Wei,2001; Broner et al.,2012) to test the economic influence of environmental regulations. However,

\footnotetext{
${ }^{1}$ For example, on December 15, 2011, the State Council of the People's Republic of China issued the 12th FiveYear Plan for National Environmental Protection (2011-2015), which requires the total sulfur dioxide emissions not to exceed 20.864 million tons by 2015 , achieving a reduction of 1.814 million tons than 2010 . On this basis, 31 provinces (excluding Hong Kong, Macao and Taiwan) will share the reduction of 1.814 million tons sulfur dioxide emissions. According to the 12th Five-Year Plan for the protection of the ecological environment in Hebei Province, Hebei province explicitly requires a reduction of at least 95,400 tons on sulfur dioxide emissions from 2011 to 2015. ${ }^{2}$ For example, the Comprehensive Emission Standards for Atmospheric Pollutants, formulated by the central government, stipulates that the emission centration of sulfur dioxide from new sources of pollution should not exceed $550 \mathrm{mg} / \mathrm{m}^{3}$. However, Shanghai's Comprehensive Emission Standards for Air Pollution requires that the maximum emission concentration of sulfur dioxide from new sources should not exceed $200 \mathrm{mg} / \mathrm{m}^{3}$.

${ }^{3}$ For example, Chinese president Xi Jinping held a conference with the new leaders of the All-China Federation of Trade Unions(ACFTU) and delivered an important speech in Beijing, China, Oct. 29, 2018.
} 
due to the potential measurement errors and omitted factors, the specifications suffer from the endogenous issues based on these measures. Different from the existing literature, we take use of the regional environmental legislation in China's market as the quasi-natural experiment to avoid the potential endogeneity. Based on the DID method, our research provides more accurate estimation on the impact of local environmental legislation on employment. In addition, we further explore the potential mechanisms behind the documented effects, including firm's entry and exit, export, and R\&D investment. Our critical and robust analysis provides crucial policy implications.

This paper uses China's local environmental legislation events and a longitudinal manufacturing data from the China Industry Business Performance Database from 1998 to 2013 to explore the impact of environmental legislation on employment growth at firm level based on the DID method. And the study makes the following contributions. First, due to the differences in timing, intensity, and other details of law enforcement among different regions in China, using national level policy as the exogenous event, such as "Two Control Zone" policy revised in 2000 to prevent and control acid rain and sulfur dioxide, is inaccurate to estimate the effect of environmental legislation on employment growth. In this research, we collect the environmental legislation events in 31 provinces from 1998 to 2013, including the passage and implementation of Environmental Protection Regulations and Environmental Pollution Prevention Regulations. Based on the province-firm samples and DID method, the firm's employment growth under environmental legislation in each province can be more accurately identified and the problem of clustering bias existing in the use of macro data is also avoided. Therefore, this paper provides more accurate estimation on the effect of environmental legislation on employment growth. Secondly, our paper further studies the potential mechanisms behind the impact of environmental legislation on employment. Revealing the micro mechanism behind the effect of environmental legislation on employment growth help provide important policy implications and suggestions regarding how to balance the environmental protection and employment growth. Thirdly, the margins of employment adjustment at the firm level have important distributional implications for the affected labor force. Our paper further decomposes the net employment growth into job creation and job destruction and estimates the effect of environmental legislation on each of them respectively. In addition, we further explore how the regulated firms change their entry and exit decision due to environmental legislation, offering new insight to the distributional impacts of regulation on the affected labor force.

The remainder of this paper is organized as follows. Section 2 provides theoretical analysis and research hypotheses. Section 3 describes the methodology and data. Section 4 describes the empirical results. Section 5 presents further analysis based on labor reallocation. Finally, section 6 concludes and discusses the potential policy implications.

The impact of environmental legislation on the labor market is uncertain. On one hand, more stringent environmental regulation leads to higher production costs, which causes enterprises to 
raise product prices thereby lowering demand for its output, thus reducing demand for inputs, including labor (this is referred to as the output effect). On the other hand, to comply with the new, more stringent regulations, enterprises must hire workers to install and maintain pollution abatement equipment, or alter their production process to reduce pollution, which may require more or less workers than those required in the previous production process. Thus, after undertaking compliance efforts, enterprises' demand on labor may be different compared with that prior to the regulation (this is referred to as the substitution effect). However, in terms of the impact of environmental legislation on employment growth in China, the mode and the mechanism of influence of these two effects are quite different. As a typical method of command-and-control environmental regulation, China's environmental legislation deals with the environmental issues via the following channels. First, environmental legislation requires governments to set emission standard for major pollutants, and the higher-level governments will supervise and assess the environmental protection departments of lower-level governments and their official leaders, the assessment results are treated as an important basis for the appointment and promotion of local officials. Second, China's environmental legislation requires relevant administrative departments, such as the National Development and Reform Commission, to set the industries with high-pollution and high-energyconsumption in the list of phase-out and restricted industries when formulating regional industrial policies. For the firms in the list of phase-out and restricted industries, restrictive measures such as differential electricity tariffs, differential sewage charges, restriction or cessation of production and operation may be adopted. Third, China's environmental legislation provides sewage permit management for pollutant emission. The firms apply for sewage permit from the local environmental protection department, and the sewage permit specifies the types, concentration, total amount, modes, and other relevant details of emission. Firms must discharge pollutants in accordance with the requirements in the sewage permit. In addition, firms must regularly reveal the pollution information, such as name, discharge modes, emission concentrations, excess emissions and the construction and operation of pollution prevention and control facilities to the public. Fourth, local environmental protection departments may punish firms that do not meet the requirements of the emission standards, including fine, rectification within a limited time, restriction on production, shutdown, and closure.

It should be noted that the above-mentioned environmental regulations are usually 
implemented in a short time in China. For example, the annual assessment of local officials in the environmental protection department is usually implemented at the end of each year, and the required time limit of rectification for the enterprises that discharge excessive pollutants is within three months. In such a short period of time, it is difficult for the regulated enterprises to achieve clean transformation by adding emission reduction equipment or changing the production process. Therefore, the environmental legislation has evolved into a "constraint" to restrict the production and operation of enterprises, resulting in less complementary effect of environmental regulation on employment. Moreover, some firms take use of rectification or temporary shutdown to deal with the inspection of environmental protection department rather than clean transformation of the production process. In addition, penalties such as fine, shutdown and closure directly increase the cost and the employment growth is adversely affected because of the increasing production cost and shrinking production scale. This is consistent with the negative impact of environmental regulation on enterprises' employment growth documented in other countries in recent years. For example, Wagner et al. (2014) find a significant 7\% reduction of employment of the European Union Emissions Trading Scheme (EU EST) in regulated firms in Phase II. Marin and Vona (2017) indicate an increase in energy price (as proxies of environmental regulation) had a modestly negative impact on employment (-2.6 percent) for French manufacturing establishments. Bailey and Thomas (2017) verify the more-regulated American industries experienced fewer new firm births and slower employment growth in the period 1998-2011. Based on the above analysis, we propose:

Hypothesis 1: The local environmental legislation has a negative impact on employment growth of China's manufacturing firms.

Firm's entry and exit could be an important channel that the environmental legislation affects the labor demand. Theoretically, new environmental laws require the enhanced investment on environment friendly equipment and technology, resulting in a high compliance cost. As a result, environmental legislation could raise the barriers for new firm to enter. In the meantime, firms with low productivity have to exit the market, as they cannot meet the high standards under the new laws (Tombe and Winter, 2015). The existing literatures have widely shown that environmental legislation has crucial impact on firm's entry and exit. Becker and Henderson (2000) discover the Clean Air Act [CAA] and its Amendments from 1970 reduced the birth of plants in non-attainment counties, compared with attainment counties. With the advent of regulation, net present value for a 
typical new plant in a non-attainment area could fall by $25-45 \%$. Jefferson et al. (2013) conclude that the stringent requirements of the Two Control Zone (TCZ) policy encouraged the entry of more productive firms and the exit of less productive ones. In China, Yang et al. (2021) also find evidence that stricter environmental regulation increased the probability of exit for the firms with lower productivity and reduced the probability of entry for those potential pollution-intense entrants, leading to significant resource reallocation within the industries. As jobs could be provided by new firms and firms that exit the market are associated with job loss, the entry and exit of firms inevitably affect the local labor market. Based on the above analysis, we propose:

Hypothesis 2: Firm's entry and exit is an important channel that local environmental legislation affects employment growth.

Another important channel that new environmental regulations affect employment growth is export. It has been widely shown that export has significant impact on the labor market. Export not only increases the demand for labor but also leads to the change of relative demand of heterogeneous labor, and such adjustments further affect the distribution of positions, wages and so on. According to the traditional Heckscher-Ohlin model (Ohlin, 1933) and the Stopler-Samuelson Theorem (Stopler and Samuelson, 1941), the exported goods are usually associated with high technology in the developed countries. Thus, the export expansion increases the demand for talents and results in a higher skill premium, while it is opposite in the developing countries. Dooley et al. $(2003,2004)$ argue that China sought to raise urban employment by 10-12 million persons per year, with about $30 \%$ of that coming from export growth. Feenstra and Hong (2010) estimate that export growth over 1997-2002 contributed at most 2.5 million jobs per year in China. Hummels et al. (2010) find exogenous exporting shocks raised Danish workers' employment and wages uniformly across all education types. Dauth et al. (2014) verify the regions specialized in export-oriented industries experienced stronger employment gains and lower unemployment in Germany.

However, environmental legislation could both positively and negatively affect firm's export because of internality of cost and improvement on R\&D investment. On the one side, environmental regulations force the firms to internalize the externality of pollution, leading to the higher production cost (Xu, 2016; Arimura, 2002). Due to the increasing cost on production, less capital can be invested on searching for overseas market, building marketing network, etc., resulting in less export expansion. Mani and Wheeler (1998) discover that high-standard environmental regulation 
diminished the comparative advantage of the related industry and made difference on trade patterns.

246 Cole et al. (2005) find that pollution abatement costs within an industry was a statistically significant negative determinant of that industry's competitiveness measured by Revealed Symmetric Comparative Advantage (RSCA) and net exports. On the other side, Porter Hypothesis points that proper environmental regulation could promote $R \& D$ and innovations, and the improved production efficiency helps reduce the production cost instead. With the technology innovation effect, environmental regulation could enhance the firm's competitiveness and positively affect export expansion. Costantini and Crespi (2008) show that countries with stringent environmental standards have a higher export capacity for those environmental-friendly technologies that regulation induces to adopt. Costantinia and Mazzanti (2012) verify Porter Hypothesis, namely the environmental policies were not harmful for export competitiveness of the manufacturing sector. In contrast, specific energy tax policies and innovation efforts positively influenced export flows dynamics. In sum as environmental legislation could also positively and negatively affect export. Based on the above analysis, we propose:

Hypothesis 3: Export is an important channel that local environmental legislation affects as a response, firms may update their production processes and invest more on pollution controls. Porter Hypothesis points that the proper environmental regulation could promote innovation and R\&D. Due to the potential technology innovation, environmental regulation could improve firms' productivity and competitiveness, and we define it as innovation compensation effect. However, it may have a negative impact on the firm's technological innovation because the total amount of capital is fixed in a certain period for a firm and the increase of investment in pollution control will crowd out other R\&D investment. As our paper mainly estimates the difference in firms' employment growth in 3 years before and after local environmental legislation, the time is short that firms are difficult to refinance. So the increase of firms' investment of the pollution control is likely to crowd out the R\&D funds, which leads to a negative impact of environmental legislation on technology innovation. However, the impact of the fall in technical innovation on the firms' employment growth is uncertain. On the one hand, technological innovation fall may reduce firm's productivity and increase labor demand per unit of product, which means firms must hire more 
labors to maintain the same level of output. In this case, technological innovation fall expands the demand for labor. On the other hand, the decline of technological innovation increases the unit production cost of firms, so the firm's price advantage decreases relative to their competitors. As a result, the market demand for products gradually shrinks and the production scale of firms also decreases, thus reducing the demand for labor and generating employment substitution effect. Based on the above analysis, we propose:

Hypothesis 4: Technological innovation is an important channel that local environmental legislation affects employment growth.

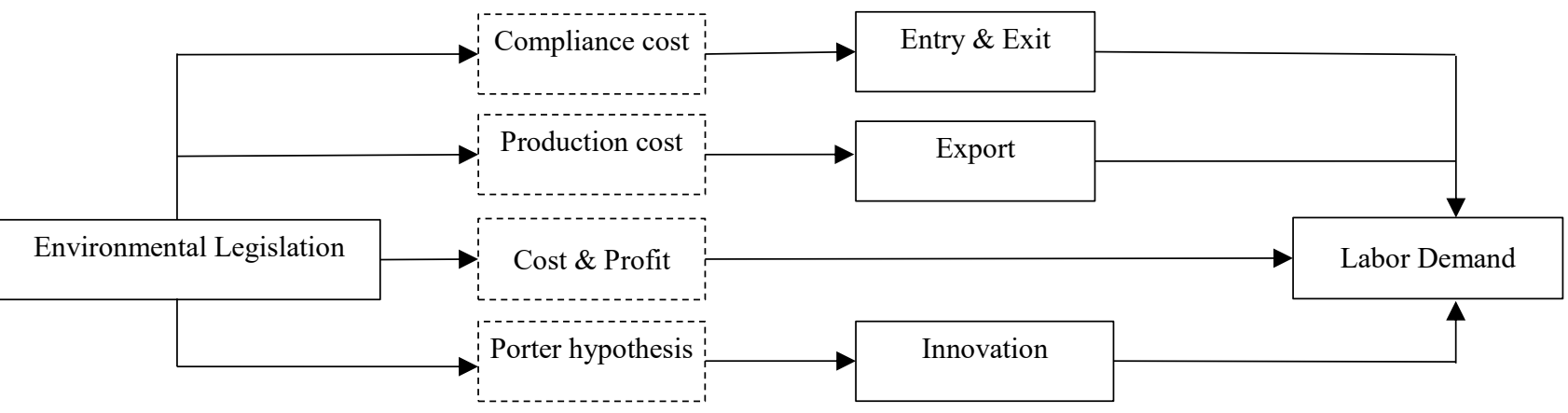

Figure 1. Theoretical analysis

\section{Methodology and Data}

\subsection{Data Sources}

The data of local environmental legislation is collected from the official website of provincial Ecology and Environment Bureaus. There are different types of local environmental legislation, including comprehensive environmental legislation (e.g., Environmental Protection Regulations, which serves as the basic framework of China's environmental legislation), and individual legislations for specific pollutants, (e.g., Law of the PRC on Prevention and Control of Water Pollution, Law of the PRC on Prevention and Control of Air Pollution, and Law of the PRC on Prevention and Control of Environmental Pollution by Solid Wastes). Figure 2 depicts the number of China's local environmental legislation since the Reform and Opening Up ${ }^{4}$. It can be roughly divided into four stages: the initial stage (1981-1989), the development and improvement stage (1990-2004), the relative decline stage (2005-2013), and the sustained and rapid development stage (after 2014). Especially, after the implementation of the Legislative Law of the People's Republic of China in 2015, the legislative power of local governments has been enhanced. Before 2015, the power of environmental legislation was only delegated to 31 provinces and 49 specific cities. After

\footnotetext{
${ }^{4}$ In this part, the local environmental legislation mainly includes the Environmental Protection Regulations, Water Pollution Prevention Regulations, Air Pollution Prevention Regulations and Solid Waste Pollution Prevention Regulations.
} 
2015, the power of local legislation was extended to all 282 districted cities. Under this circumstance, the number of local environmental legislation has increased rapidly. From 1978 to 2015, the total number of local environmental legislations in China was 144. But in the following five years, the number of legislations reached 72 , accounting for half of the total number of previous legislations.

The firm level data is obtained from Chinese Industrial Enterprise Data (CIED), and the sample period is from 1998 to 2013. Due to the statistical issues such as abnormal indicators and obvious measurement errors in this set of data, we filter the original data according to the ideas provided by Brandt et al. (2012). We delete the observations with total output less than 5 million; we delete the observations with negative or missing values of total income, employment, fixed assets, total sales, or intermediate input; we delete those firms whose establishment year is earlier than 1949, and delete the firms with age less than 0 ; we delete the observations with less than 8 employees at the end of the year; we delete the observations of firms with obvious mistakes, such as the sample with total assets less than current assets. Due to the lack of information on the "industrial added value" of firms in 2004, we estimate it according to the accounting principles (industrial added value = total industrial output value-industrial intermediate input + value-added tax).

The information of GDP per capita, urbanization level, green area per capita, total number of industrial firms, total labor force, and total urban industrial output value of each region is obtained from "China Statistical Yearbook". The data regarding to regional pollution and environmental information is obtained from "China Environment Yearbook".

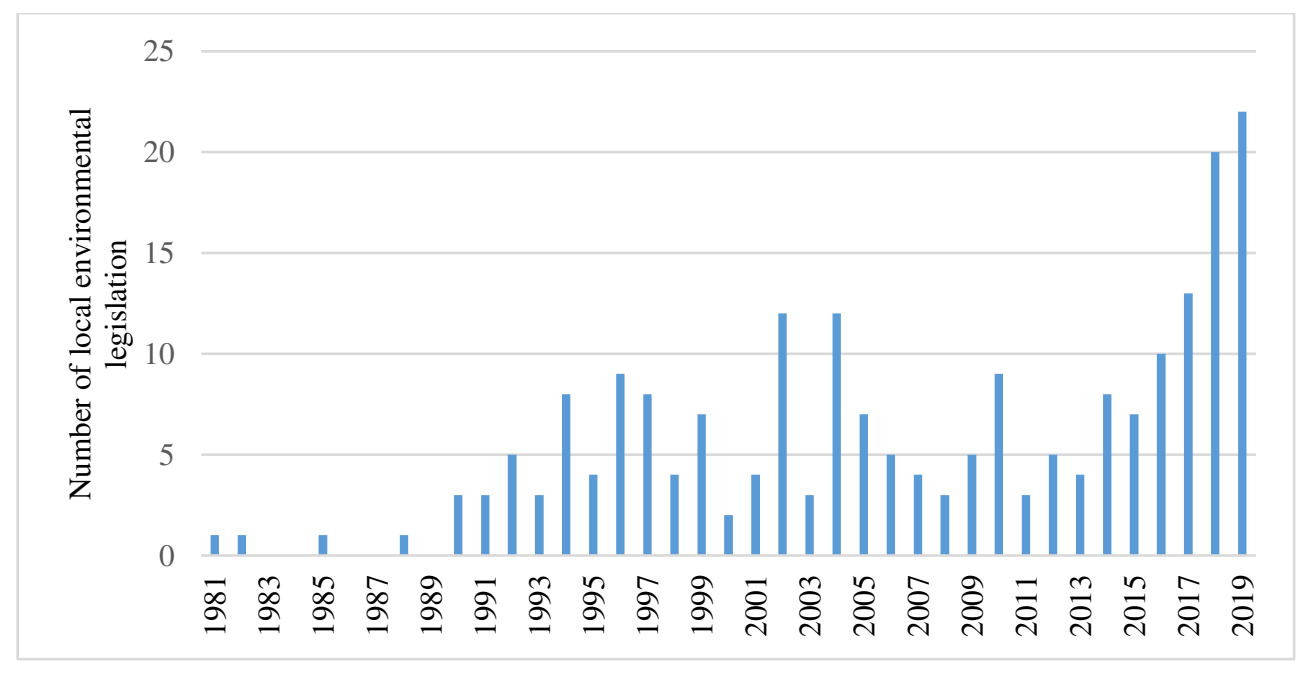

Figure 2. Annual distribution of China's local environmental legislation

\subsection{Methodology}

This article uses the local environmental legislation events to identify the impact of environmental legislation on the employment growth of Chinese manufacturing firms based on difference-in-difference model. First, we collect the data of environmental legislations of China's 31 provinces, including the "Environmental Protection Regulations" and "Pollution Prevention Regulations". Secondly, the provinces with environmental legislations are regarded as the experimental group, and the unlegislated provinces are regarded as the control group. In order to ensure that the employment growth in control group follows the same trend $\mathrm{s}$ as the experimental 
group before legislation, this paper selects control groups based on the following principles. First, the provinces are treated as the control group only if there is no relevant legislation passed in the 3 years before or after the legislation has been passed. Second, the average annual growth rate of employment in the control group should be similar to that in the experimental group during the 3 years before the legislation has been passed. Finally, it must be noted that due to the number of provinces with legislation is far more than the unlegislated provinces in some years, the control group is not completely available for some special legislative provinces. Furthermore, in order to overcome the interference of regional characteristics that do not vary over time, province fixed effects are controlled. The basic settings of the model are as follows:

$$
\text { job_growth } \text { gft }_{1}=\alpha_{1} \text { treatment }_{p} \times \text { post }_{t}+\alpha_{2} X+\delta_{p}+\delta_{t}+\mu_{p f t}
$$

where the dependent variable job_growth ${ }_{p f t}$ represents the employment growth of firm $f$ in province $p$ from year t-1 to t. Treatment ${ }_{p}$ represents a dummy variable indicating whether province $p$ is in treatment group or not. If one province has passed environmental legislation, it is treated as the experimental group and the value of treatment is 1 . Otherwise, treatment equals 0 . Post is a dummy variable indicating whether the year is during the three years after the environmental legislation has been enacted. In the special situation that an environmental law has been revised repeatedly, we deal with it with following principle: if the law is revised in the fifth year or even later after it was first passed, it will be regarded as two different laws. And if the law is revised within five years, they will be treated as the same law. And if the dates of enactment and implementation of environmental laws are not in the same year, this paper uses the time of enactment as the time of environmental legislation. And the reason for that is Chinese firms, especially state-owned firms, are very sensitive to the government policies and may respond before the policy is formally implemented. The coefficient of treatment*post measures the difference in employment growth between the experimental group and the control group after the environmental legislation, and it reflects the average impact of environmental legislation on employment growth at firm level. The variable $X$ represents other factors that affect the employment growth of Chinese manufacturing firms, including firm's size(size), firm's age(age), whether the firm is a state-owned firm or not (soe), whether the firm exports or not (export), firm's productivity(lntfp), firm's capital intensity ( $\operatorname{lnkl}$ ), GDP per capita in the province where the firm is located ( $\operatorname{lng} d p)$ and urbanization level (urbanization). $\delta_{p}$ and $\delta_{t}$ represent regional fixed effects and time fixed effects respectively, and $\mu$ $p f t$ is the random error term.

\subsection{Variable Description and Statistical Description}

Job_growth in Equation (1) represents the employment growth of the firm $f$, which is measured by the growth rate of employees in firms over time. Firm's employment growth may originate from two aspects. One is the growth in the number of employees in the existing firms, and the other is the employment growth caused by the firms' entry and exit. Following Davis and Haltiwanger(1992), Job_growth is measured as: 


$$
j o b_{-} \text {growth }_{p f t}=\frac{e_{p f t}-e_{p f t-1}}{\left(e_{p f t}+e_{p f t-1}\right) / 2}
$$

where $e$ represents the employment level, measured as the number of employees of each firm at the end of the year. The employment growth calculated by this method is a monotonic function and the value is between $[-2,2]$. The employment growth caused by firm's entry or exit can also be measured in the equation, where -2 represents the firm's exit and 2 corresponds to firm's entry.

In addition, Equation (1) also includes other control variables that affect growth in firm's employment, including both firm-level variables and regional variables: firm's size(size), measured as the logarithm of the total output, and firm's age (age), measured as the year minus the year of establishment of the firm. We also control dummy variable $S O E$ indicating whether the firm is stateowned or not. State-owned firms are affected by government administrative orders and central plans, and they need to fulfill additional "social responsibility", which leads to slower adjustment in their employment structure when facing external shocks. The export dummy variable (export) indicating whether the firm exports or not. Compared with non-export firms, export firms are usually larger in scale and have relatively larger size of employment. At the same time, the "learning by doing" effect of export can increase the productivity of firms that indirectly affects the employment growth. The total factor productivity $(\operatorname{lntfp})$ is also controlled in our analysis. The existing literature mostly uses the OP method (Olley and Pakes, 1996) and the LP method (Levinsohn and Petrin,2003) to estimate firms' total factor productivity. However, as the key indicators (e.g., industrial added value and intermediate input) are missing in the CIED after 2007, we approximately calculate firms' total factor productivity by $A T F P=\ln Q / L-s \ln K / L$ (Head and Ries,2003), where $Q$ is approximately replaced by the total industrial output value, $K$ is the total fixed assets, $L$ is the number of employees, $s$ represents the contribution of capital in the production function, which is set to $1 / 3$ (Hall and Jones, 1999). Productivity not only affects the overall employment level, but also affects the skill structure and gender structure of employment in a firm. Capital intensity $(\operatorname{lnkl})$ is the ratio of the total assets to the number of employees at the end of year, reflecting the amount of capital allocated to a unit of labor force. Labor-intensive firms have a higher level of employment, but capital-intensive firms may employ more highly skilled labor. Local GDP $(\ln g d p)$ is controlled as regions with a higher degree of economic development can better gather advantageous resources and provide local residents with a large number of employment opportunities and higher wage. In addition, we also control the level of regional urbanization (urbanization), measured as the proportion of urban population in the total population of each province.

Table 1 reports the descriptive statistics of the main variables for the control group and the treatment group, respectively. It is shown that, except for export, there are significant differences in other variables between legislative and non-legislative regions. The average employment growth rate, scale, and capital-labor ratio in legislative areas are higher, but the average firm's size and capital labor ratio are relatively smaller. The proportion of non-state-owned firms in the legislative regions is higher. But compared with non-legislative regions, there is no significant difference in 
the proportion of export firms. The mean difference of the regional variables lngdp and urbanization is significant, indicating that GDP per capita level in legislative regions is higher and the urbanization rate is also higher than that of non-legislative regions. It should be noted that although the average employment growth of firms in the legislative regions is higher than that in the nonlegislated regions and the difference is significant at the statistical level of 5\%. The test of difference in the mean value of each variable is independent. At the same time, the results in Table 1 describes the average change of each variable during the entire sample period without considering the differences before and after the legislative period.

Table 1. Descriptive statistics of variables

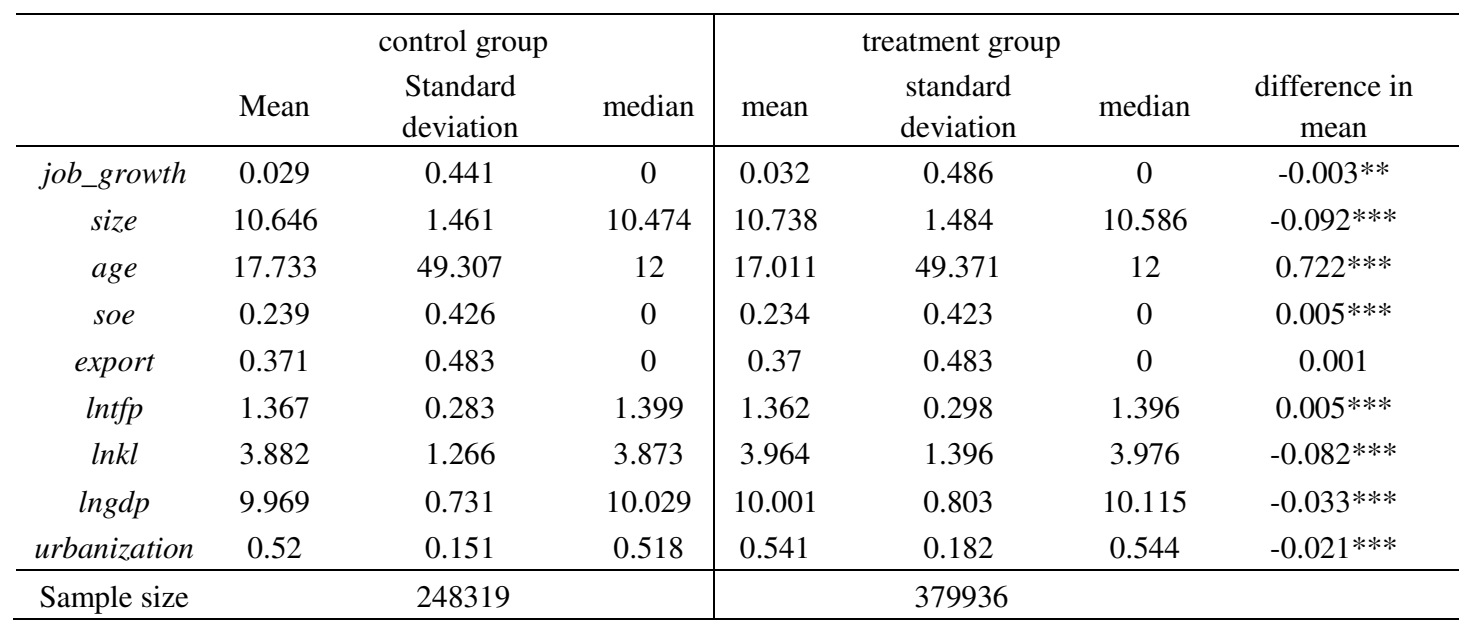

Note: $* * * * *$, and $*$ refer to statistical significance at $1 \%, 5 \%$, and $10 \%$ respectively.

\section{Empirical Analysis and Discussion}

\subsection{Benchmark Regression}

In order to ensure the validity of the regression results, we respectively use the OLS model and the fixed effect model estimating Equation (1). As shown in Table 2, Column (1) and (2) are the regression results of OLS model, and Column (2) adds a firms fixed effect to Column (1) to control the impact of firms' individual characteristics that do not change over time. At the same time, taking the possible sequence correlation and heterogeneous problems into account, we cluster the regression standard deviations at the industry level in Column (1) and (2). Column (3) - (5) are the regression results of fixed effect model, and Column (4) and (5) add time fixed effect and regional fixed effect to control the impact of macroeconomic and regional factors on firms' employment growth that do not change over time. All the regression results show that, after controlling the firms'

431 individual characteristics and macroeconomic factors, the employment growth of manufacturing 
unregulated firms (control group). The results show that after the implementation of environmental

434 legislation, the employment growth of regulated manufacturing firms decreases significantly by

$4353.07 \%$ (Column 2 and 5), so the Hypothesis 1 is validated. The possible reason for this result is that

436 the employment substitution effect produced by the implementation process and judicial practice of

437 local environmental legislation in China far exceeds the employment complementary effect,

438 resulting in a negative impact on the labor demand. In fact, the Environmental Protection

439 Regulations formulated by local governments in China, including sewage permit, emission standard,

440 or government fine, closure and bankruptcy imposed on the non-compliant firms, have become strict

441 constraints. The production cost raises because of the internalization of environmental protection,

442 leading to a shrinking production scale, and thus it is difficult to maintain the sustained employment

443 growth for the regulated firms. On the other hand, in China, the special promotion mechanism of

444 local officials in environmental protection department also ensures that officials have sufficient

445 incentive to supervise firms' environmental performance, and the potential penalties for the non-

446 compliant firms have become the "Sword of Damocles".

447

Table 2. Benchmark regression

\begin{tabular}{|c|c|c|c|c|c|}
\hline & $\begin{array}{c}(1) \\
\text { job_growth }\end{array}$ & $\begin{array}{c}\text { (2) } \\
\text { job_growth }\end{array}$ & $\begin{array}{c}\text { (3) } \\
\text { job_growth }\end{array}$ & $\begin{array}{c}\text { (4) } \\
\text { job_growth }\end{array}$ & $\begin{array}{c}\text { (5) } \\
\text { job_growth }\end{array}$ \\
\hline & OLS & OLS & $\mathrm{FE}$ & $\mathrm{FE}$ & $\mathrm{FE}$ \\
\hline \multirow[t]{2}{*}{ treatment $\times$ post } & $-0.0225^{* * *}$ & $-0.0307^{* * * *}$ & $-0.0411^{* * *}$ & $-0.0307^{* * *}$ & $-0.0307^{\text {*** }}$ \\
\hline & $(-7.5176)$ & $(-7.8595)$ & $(-22.5803)$ & $(-14.9114)$ & $(-14.9297)$ \\
\hline \multirow[t]{2}{*}{ size } & $0.0735^{* * *}$ & $0.2865^{* * *}$ & $0.2924^{* * *}$ & $0.2866^{* * *}$ & $0.2865^{* * *}$ \\
\hline & $(21.7077)$ & $(38.6844)$ & (114.0812) & (110.7045) & (110.6533) \\
\hline \multirow[t]{2}{*}{ age } & $-0.0006^{* * * *}$ & $-0.0001^{* * *}$ & $-0.0001^{* * * *}$ & $-0.0001^{* * * *}$ & $-0.0001^{* * * *}$ \\
\hline & $(-7.6465)$ & $(-4.5188)$ & $(-4.7923)$ & $(-5.1793)$ & $(-5.1818)$ \\
\hline \multirow[t]{2}{*}{ soe } & $-0.0299^{* * * *}$ & $-0.0528^{* * *}$ & $-0.0483^{* * * *}$ & $-0.0527^{* * * *}$ & $-0.0528^{* * * *}$ \\
\hline & $(-3.0248)$ & $(-8.1045)$ & $(-17.9014)$ & $(-19.2971)$ & $(-19.3246)$ \\
\hline \multirow[t]{2}{*}{ export } & $-0.0507^{* * *}$ & $-0.0137^{* * *}$ & 0.0026 & $-0.0137^{* * *}$ & $-0.0137^{* * *}$ \\
\hline & $(-7.2851)$ & $(-3.4824)$ & (1.1119) & $(-5.8752)$ & $(-5.8802)$ \\
\hline \multirow[t]{2}{*}{$\ln t f p$} & $-0.1706^{* * *}$ & $-0.8861^{* * *}$ & $-0.9207^{* * *}$ & $-0.8864^{* * *}$ & $-0.8861^{\text {*** }}$ \\
\hline & $(-9.1324)$ & $(-21.6795)$ & $(-62.9936)$ & $(-60.4055)$ & $(-60.3820)$ \\
\hline \multirow[t]{2}{*}{$\ln k l$} & $-0.0829^{* * *}$ & $-0.2086^{* * *}$ & $-0.2042^{* * *}$ & $-0.2086^{* * * *}$ & $-0.2086^{* * *}$ \\
\hline & $(-23.3250)$ & $(-73.0205)$ & $(-206.5392)$ & $(-187.9120)$ & $(-187.8922)$ \\
\hline \multirow[t]{2}{*}{$\ln g d p$} & $0.1216^{* * * *}$ & $0.0648^{* * * *}$ & $-0.0193^{* * *}$ & $0.0648^{* * * *}$ & $0.0648^{* * * *}$ \\
\hline & (9.3999) & (6.1388) & $(-5.8716)$ & (13.1939) & (13.1908) \\
\hline \multirow[t]{2}{*}{ urbanization } & $-0.3024^{* * * *}$ & -0.0697 & $0.1177^{* * *}$ & $-0.0685^{*}$ & $-0.0697^{*}$ \\
\hline & $(-5.2548)$ & $(-1.0099)$ & (3.5694) & $(-1.9249)$ & $(-1.9263)$ \\
\hline Costant & $-1.0383^{* * *}$ & $-1.4356^{* * *}$ & $-0.8846^{* * *}$ & $-1.5040^{* * * *}$ & $-1.4356^{* * * *}$ \\
\hline
\end{tabular}




\begin{tabular}{cccccc}
\hline & $(-9.4318)$ & $(-12.0817)$ & $(-41.7320)$ & $(-36.3959)$ & $(-20.6397)$ \\
time-fixed effect & Yes & Yes & No & Yes & Yes \\
firms-fixed effect & No & Yes & Yes & Yes & Yes \\
region-fixed effect & Yes & Yes & No & No & Yes \\
\hline$N$ & 577408 & 577408 & 577408 & 577408 & 577408 \\
adj. $R^{2}$ & 0.1095 & 0.2406 & 0.2601 & 0.2659 & 0.2660 \\
\hline
\end{tabular}

Note: $t$ values of the regression coefficient are in parentheses. ${ }^{* * *}, * *$, and $*$ refer to statistical significance at $1 \%, 5 \%$, and $10 \%$ respectively.

\subsection{Mechanism Test}

Based on Hypothesis 2,3 and 4, this paper will test the mediating effects of firms' entry and exit, export and innovation with mediation effect model, and the specific expression is as follows:

$$
\left\{\begin{array}{c}
\text { job_ }_{-} \text {growth }_{p f t}=\alpha_{1} \text { treatment }_{p} \times \text { post }_{t}+\alpha_{2} X+\delta_{p}+\delta_{t}+\mu_{p f t} \\
M=\beta_{1} \text { treatment }_{p} \times \text { post }_{t}+\beta_{2} X+\delta_{p}+\delta_{t}+\mu_{p f t} \\
\text { job_growth }_{p f t}=\gamma_{1} \text { treatment }_{p} \times \text { post }_{t}+\gamma_{2} M+\gamma_{3} X+\delta_{p}+\delta_{t}+\mu_{p f t}
\end{array}\right.
$$

Where $M$ in Equation (3) represents the intermediary variable and other variables are the same as those in Equation (1). The steps of testing the mediating effect are as follows. The first step is to check whether the coefficient $\alpha_{l}$ is significant. The test of mediating effect is meaningful only if $\alpha_{l}$ is significant. The second step is to check whether the coefficients $\beta_{1}$ and $\gamma_{2}$ are significant. If both coefficients are significant, then the mediating effect of $M$ is proved. Third, we need to check whether the estimated coefficient $\gamma_{l}$ is significant. If the coefficient $\gamma_{l}$ is significant, it means that the mechanism $M$ can partially explain the influence of the core independent variable on the dependent variable. If the coefficient $\gamma_{l}$ is not significant, it indicates that the mechanism $M$ can fully explain the influence of the core independent variable on the dependent variable.

\subsubsection{Firm's Entry and Exit Effect}

To test the mediation effect of firm's entry and exit, we choose the firm's entry and exit state as intermediary variable $M$, which is defined as follows: if one firm does not exist in period T-1 or before, but begins to exist in period $\mathrm{T}$, it is defined as the firm's entry (entry $=1$, otherwise it is 0 ); If the firm exists in period T-1 and before, and disappears from period T, it is defined as firm's exit (exit $=1$, otherwise 0 ). We use Probit and Logit models to estimate how local environmental legislation affects firm's entry and exit, respectively. Column 1,2, 4 and 5 in table 3 show estimated results of the second step in Equation 3; Column 3 and 6 show the regression results of the last step in Equation 3. And the regression results of the first line in Equation 3 are the same as those in benchmark regression. As shown in Table 3, the local environmental legislation could result in 
higher probability of firm exit and lower probability of entry, and thus lower labor demand,

474 supporting Hypothesis 2. The possible reason is that environmental legislation requires higher

475 environmental standards and increases the productivity threshold for firms to enter the market,

476 which means only those high-productivity firms that meet the emission requirements will choose to

477 enter the market. At the same time, some low-productivity firms may exit the market because they

478 fail to meet new emission standards and production technology requirements. In the short term, less

479 entry and more exit in the market resulting from the environmental legislation has a negative impact

480 on the labor market.

Table 3. Impact mechanism test based on firm entry and exit

\begin{tabular}{ccccccc}
\hline & $(1)$ & $(2)$ & $(3)$ & $(4)$ & $(5)$ & $(6)$ \\
\hline & Probit & Logit & OLS & Probit & Logit & OLS \\
\hline entry & entry & job_growth & exit & exit & job_growth \\
\hline treatment $\times$ post & $-0.1847^{* * *}$ & $-0.3107^{* * *}$ & $-0.0186^{* * *}$ & $0.4032^{* * *}$ & $0.8288^{* * *}$ & $-0.0212^{* * *}$ \\
& $(-3.9999)$ & $(-3.6726)$ & $(-6.5409)$ & $(12.637)$ & $(11.83)$ & $(-7.5505)$ \\
entry & & & $1.9775^{* * *}$ & & & \\
& & & $(400.4515)$ & & & \\
exit & & & & & & $-0.0330^{* * *}$ \\
& & & & & & $(-5.4590)$ \\
control variable & Yes & Yes & Yes & Yes & Yes & Yes \\
time-fixed effect & Yes & Yes & Yes & Yes & Yes & Yes \\
region-fixed effect & Yes & Yes & Yes & Yes & Yes & Yes \\
Industry-fixed effect & Yes & Yes & Yes & Yes & Yes & Yes \\
\hline$N$ & 639331 & 639331 & 626241 & 602131 & 602131 & 553298 \\
\hline
\end{tabular}

483

484

485

486

487

488

489

490

491

492

Notes: Control variables include size, age, soe, export, lntfp, lnkl, lngdp and urbanization. The others are the same as in Table 2.

\subsubsection{Export Effect}

The increase in "compliance cost" caused by environmental legislation squeezes out the expenses on exploring foreign markets and reduces the probability of export. Therefore, environmental legislation may reduce the employment growth of firms via the reduction in export.

However, for firms that have already entered the export market, because the export fixed cost has been paid, the innovation compensation effect of environmental legislation under the "Porter Hypothesis" may exceed the decline of export competitiveness caused by the increase of 
"compliance cost", and thus maintain a continuous growth of export scale. Taking these situations

494 into consideration, we respectively select firms' export decision (export or not) and export scale as

495 intermediary variables and use the mediation effect model to test whether export effect serves as an 496 important channel that explains the effect of environmental legislation on firms' employment growth.

497 In table 4, Column 1 and 4 show the regression results of the first step in Equation 3; Column 2 and 4985 show the regression results of the second step in Equation 3; Column 3 and 6 present the regression results of the third step in Equation 3. In order to verify this mechanism, we test how the 500 environmental legislation affects local firm's export decision (Column 1-3) and export scale 501 (Column 4-6). Shown in Column 2 and 5 of table 4, the local environmental legislation negatively 502 affects the export decision of non-export firms, but positively affects the export scale of the 503 surviving export firms, consistent with our expectation. As the sample including both firms with 504 export and those without, in Column 2 we use Heckman two-step method to deal with the potential 505 selection bias. In Column 3 and 6, we also controlled the export decision/scale, and the results are 506 consistent with Hypothesis 3. In sum, the results show that the local environmental legislation has 507 a negative effect on export decision, but has a positive effect on export size of the surviving export 508 firms, resulting in the decrease in labor demand. Thus, export is an important channel that explains 509 why environmental legislation affects employment growth.

Table 4. Impact mechanism test based on export

\begin{tabular}{|c|c|c|c|c|c|c|}
\hline & (1) & $(2)$ & (3) & (4) & $(5)$ & (6) \\
\hline & \multicolumn{3}{|c|}{ Export decision (export) } & \multicolumn{3}{|c|}{ Export scale (lnexp) } \\
\hline & job_growth & export & job_growth & job_growth & $\ln \exp$ & job_growth \\
\hline \multirow[t]{2}{*}{ treatment $\times$ post } & $-0.0186 * * *$ & $-0.0654 * * *$ & $-0.0194 * * *$ & $-0.0186 * * *$ & $0.2672 * * *$ & $-0.0289 * * *$ \\
\hline & $(-6.7342)$ & $(-10.3071)$ & $(-7.2531)$ & $(-6.7342)$ & (33.9194) & $(-9.4373)$ \\
\hline \multirow[t]{2}{*}{ export } & & & $-0.0471 * * *$ & & & \\
\hline & & & $(-6.6220)$ & & & \\
\hline \multirow[t]{2}{*}{$\ln \exp$} & & & & & & $-0.0297 * * *$ \\
\hline & & & & & & $(-7.2469)$ \\
\hline \multirow[t]{2}{*}{$l a m b d a$} & & $-0.6542 * * *$ & & & & \\
\hline & & $(-104.6052)$ & & & & \\
\hline Control variables & Yes & Yes & Yes & Yes & Yes & Yes \\
\hline Time-fixed effect & Yes & Yes & Yes & Yes & Yes & Yes \\
\hline Region-fixed effect & Yes & Yes & Yes & Yes & Yes & Yes \\
\hline$N$ & 577408 & 562772 & 577408 & 577408 & 218173 & 202521 \\
\hline $\operatorname{adj} . R^{2}$ & 0.1074 & & 0.1101 & 0.1074 & 0.3797 & 0.1240 \\
\hline
\end{tabular}

511 Note: Export is a dummy variable, which equals 1 if one firm exports, and 0 otherwise. Lnexp is the 
logarithm of export value; lambda is the inverse Mills ratio estimated from Heckman Model; and control variables are the same as those in Table 2.

\subsubsection{Innovation Effect}

Porter Hypothesis points out that appropriate environmental policies can promote technological innovation of the regulated firms, improve firms' productivity and competitiveness, offsetting the "compliance cost" brought by environmental policies to some extent, and produce innovation compensation effect. However, environmental policies may have a negative impact on firm's technological innovation because the total amount of capital is fixed in a certain period for a firm and the increase of investment in pollution control will crowd out other R\&D investment. On this basis, technological innovation may reduce the unit production cost and product's price of firms and increase the market demand for products. The resulting expansion of production scale may increase the demand for labor. On the other hand, the increase in productivity may also lead to the decline of labor demand per unit of output, which may have a negative impact on the employment growth. In order to test whether environmental legislation reduces firms' employment growth through the mechanism of technological innovation, this paper uses " the output value of new products" (innovation1) and " the research and development expenses" (innovation2) from CIED as indicators of technological innovation. The mediation effect model is tested according to Equation (3).

\begin{tabular}{|c|c|c|c|c|c|c|}
\hline & (1) & (2) & (3) & (4) & $(5)$ & (6) \\
\hline & \multicolumn{3}{|c|}{ Innovation1 } & \multicolumn{3}{|c|}{ Innovation2 } \\
\hline & job_growth & innovation1 & job_growth & job_growth & innovation 2 & job_growth \\
\hline treatment $\times$ post & $\begin{array}{c}-0.0186^{* * *} \\
(-6.7342)\end{array}$ & $\begin{array}{c}-0.4827^{* * *} \\
(-9.3)\end{array}$ & $\begin{array}{c}-0.0181^{* * *} \\
(-7.88)\end{array}$ & $\begin{array}{c}-0.0186^{* * *} \\
(-6.7342)\end{array}$ & $\begin{array}{c}-0.3781^{* * *} \\
(-6.73)\end{array}$ & $\begin{array}{c}-0.0464^{* * *} \\
(-6.35)\end{array}$ \\
\hline innovationl & & & $\begin{array}{c}-0.0030 * * * \\
(-5.91)\end{array}$ & & & \\
\hline innovation 2 & & & & & & $\begin{array}{c}-0.0044 * * * \\
(-5.11)\end{array}$ \\
\hline control variables & Yes & Yes & Yes & Yes & Yes & Yes \\
\hline time-fixed effect & Yes & Yes & Yes & Yes & Yes & Yes \\
\hline region-fixed effect & Yes & Yes & Yes & Yes & Yes & Yes \\
\hline$N$ & 577408 & 385217 & 336922 & 577408 & 194091 & 193103 \\
\hline $\operatorname{adj} . R^{2}$ & 0.1101 & 0.1197 & 0.04 & 0.1101 & 0.1898 & 0.1445 \\
\hline
\end{tabular}

Notes: Control variables include size, age, soe, export, lntfp, lnkl, lngdp and urbanization. The definition of other variables is the same as those in Table 4.

Table 5 reports the test on how environmental legislation affects employment growth of manufacturing firms via innovation. Column 1 and 4 show the estimated results of step 1of Equation 

estimated results of the last step of Equation 3. In table 5, Column (2) and (5) show the estimated impact of environmental legislation on firms' technological innovation, and the results show that local environmental legislation significantly reduces firms' innovation capacity, either measured by

541 the output value of new products or the research and development expenses. This shows that "Porter

542 Hypothesis" is not established in the short term, and environmental legislation has a negative impact on firms' technological innovation mainly through squeezing out R\&D investment. Incorporating the variable of technological innovation into the benchmark model, both Column 3 and 6 show that the coefficients of both technological innovation and the core independent variable treatment xpost are significant, indicating technological innovation partially explains why the environmental legislation influences firm's employment growth. In addition, the results also show that the employment substitution effect of innovation exceeds complementary effect as lower employment level is associated with environmental legislation. To sum up, local environmental legislation reduces the technological innovation capacity of firms, and this partially explains why the firm's employment growth decreases with strict environmental legislation in China.

\subsection{Robustness Test}

\subsubsection{Parallel Trend Test}

An important prerequisite for using the DID model is to satisfy the parallel trend hypothesis. In this paper, it is required that the employment of the control group and the treatment group follow the same trend before the implementation of environmental legislation. As shown in Figure 3, we first use the graphic method to depict the employment growths of the control group and the experimental group before and after the implementation of the legislation. It is found that before the implementation of the environmental legislation, the employment curves of the control group and the treatment group are basically parallel. But after the implementation of the legislation, the employment curves of the control group and the treatment group are gradually different. This result indicates that the employment growths of the control group and the treatment group selected in our research are basically the same before the environmental legislation, and the employment growths gradually show differences after the legislation, which satisfies the parallel trend hypothesis. In addition, this paper also uses two other methods to test parallel trend hypothesis. First, the whole sample period is divided into two periods before and after legislation according to Cai et al. (2016), 
and time dummy variables bef and aft are set correspondingly. We also construct time dummy variable $B \_n(\mathrm{n}=1,2,3)$ for $\mathrm{n}$ years before the legislation and dummy variable $A \_n(\mathrm{n}=1,2,3)$ for $\mathrm{n}$ years after the legislation respectively following Hering and Poncet (2014). And the interaction items between these time dummy variables and the dummy variable of environmental legislation treatment are added to the basic regression, respectively. The regression results of the above two methods all show that before legislation, the coefficient between the time dummy variable and treatment dummy variable is not significant, but it is significantly negative after legislation ${ }^{5}$. It further shows that before the implementation of environmental legislation, there is no significant difference in the trend of employment growth between the control group and the treatment group, satisfying the hypothesis of parallel trend.

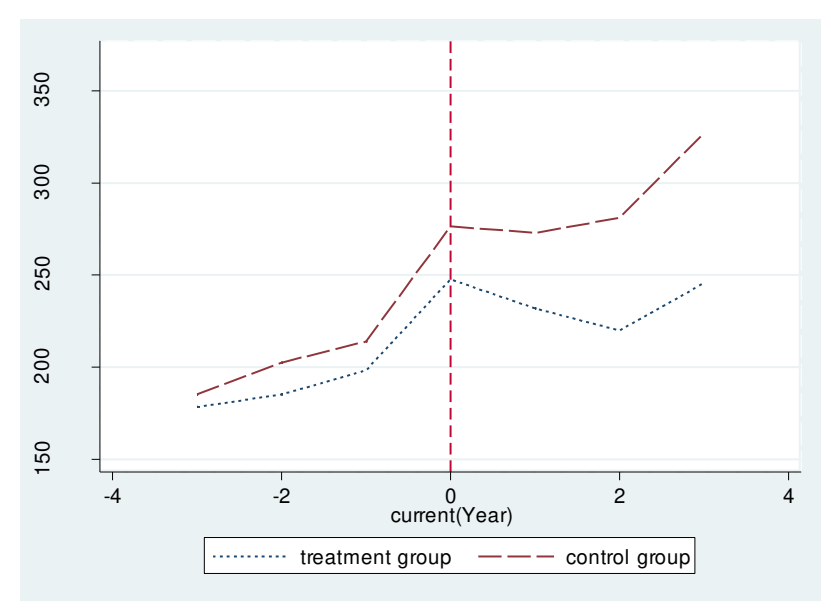

Figure 3. Employment growth before and after environmental legislation

4.3.2. Eliminating Interference from Other Policies

Another important premise for using the DID model is to exclude the interference of other policies. To obtain accurate estimates, other policies that may affect employment growth in the sample period should be controlled. In this paper, other policies may have impacts on the employment growth are summarized as follows. The first event is China's entry into the WTO in 2001. After China joined WTO, the average import tariff of China has decreased significantly. The intensified competition caused by import expansion and the technology spillover of imported products may affect the employment growth of Chinese manufacturing firms. In this regard, we further control the average import tariff and import competition intensity of the industry (Industry import penetration rate $\times$ firm's domestic sales ratio) in Column (1) to (2) of Table 6 , respectively.

5 The results of two other parallel trend tests can be seen in Table 1 in the appendix. 
With China being a member of WTO, the environment for FDI has been more friendly. The competitive effect and technology spillover caused by FDI may also affect the employment growth.

591

592 In this regard, we control the proportion of foreign capital (foreign) in Column (3). Around 2004, China carried out a substantial reform of state-owned firms, with the general trend of "private firms entering and state-owned firms exiting". The introduction of marketization increased the uncertainty faced by firms. In this regard, we control the ratio of state-owned capital to the total capital (state) in Column (4). Since the global financial crisis occurred around 2008, the difficulties of financing, especially for Chinese small and medium-sized firms, have become more prominent. Financing constraints not only affect the profit growth and scale expansion of firms, but also affect the technological development and the innovation. All these factors are important for the firm's employment growths. In this regard, we control the financing constraints (finance) in Column (5). In 2004, China formally implemented the "Minimum Wage Regulations", and various provinces and cities have also introduced their own minimum wage standards. The minimum wage not only directly affects the employment scale of firms, but also affects the structure and direction of employment adjustment. In this regard, we control for the minimum hourly wage (minwage) in the province or city where the firm is located in Column (6). Regression results in Table 6 show that with controlling the potential effects of the above-mentioned policies, the coefficient of treatment $\times$ post is still significantly negative, consistent with the results of benchmark regression, indicating that environmental legislation could reduce the employment growth of Chinese manufacturing firms.

Table 6. Regression results excluding other policy disturbances

\begin{tabular}{|c|c|c|c|c|c|c|}
\hline & (1) & (2) & (3) & (4) & (5) & (6) \\
\hline treatment $\times$ post & $\begin{array}{c}-0.023 * * * \\
(-8.0131)\end{array}$ & $\begin{array}{c}-0.0209 * * * \\
(-7.4540)\end{array}$ & $\begin{array}{c}-0.0186 * * * \\
(-9.4963)\end{array}$ & $\begin{array}{c}-0.0128 * * * \\
(-5.7779)\end{array}$ & $\begin{array}{c}-0.0087 * * \\
(-2.5607)\end{array}$ & $\begin{array}{l}-0.0069 * \\
(-1.8660)\end{array}$ \\
\hline tariff & $\begin{array}{c}-0.0016 \\
(-1.0545)\end{array}$ & & & & & \\
\hline competition & & $\begin{array}{c}-0.0022 \\
(-0.1277)\end{array}$ & & & & \\
\hline foreign & & & $\begin{array}{c}0.0455^{* * * *} \\
(6.7708)\end{array}$ & & & \\
\hline state & & & & $\begin{array}{c}-0.0400 * * * \\
(-7.1624)\end{array}$ & & \\
\hline finance & & & & & $\begin{array}{c}-0.0005 \\
(-1.0322)\end{array}$ & \\
\hline
\end{tabular}




\begin{tabular}{ccccccc}
\hline minwage & & & & & & $-0.0125^{* * *}$ \\
& & & & & & $(-5.2918)$ \\
Control variables & Yes & Yes & Yes & Yes & Yes & Yes \\
Time-fixed effect & Yes & Yes & Yes & Yes & Yes & Yes \\
Region-fixed effect & Yes & Yes & Yes & Yes & Yes & Yes \\
\hline$N$ & 475522 & 539009 & 381184 & 381184 & 521842 & 249005 \\
adj. $R^{2}$ & 0.1251 & 0.1162 & 0.0439 & 0.0434 & 0.0942 & 0.1331 \\
\hline
\end{tabular}

611 Notes: Control variables include size, age, soe, export, lntfp, lnkl, lngdp and urbanization. The

612 others are the same as in Table 2.

\section{4.3.3. Other Robustness Tests}

614 In this section, we further show the robustness of the above documented results. First, we use

615 the two-phases DID method instead of the multi-phases DID method in Column (1). Column (2)

616 shows the estimates based on PSM-DID method. In Column (3) and (4), the state-owned firms and

617 the observations with extreme values are eliminated, respectively. Column (5) and (6) show the

618 estimated results for the sub-samples with period 1998 to 2007 and 2007 to 2013, respectively, we

619 further control the firm's average wages in Column (7). In the last column, the province-time fixed

620 effect is added. As shown in Table 7, the coefficients of the interaction term are all consistently

621 significantly negative, indicating that the estimation results of benchmark regression in this paper

622 are robust.

623

624

Table 7. Other Robustness tests

\begin{tabular}{|c|c|c|c|c|c|c|c|c|}
\hline & (1) & $(2)$ & (3) & (4) & (5) & $(6)$ & $(7)$ & $(8)$ \\
\hline & $\begin{array}{l}\text { Multi-phase } \\
\text { to } \\
\text { two-phases }\end{array}$ & PSM-DID & $\begin{array}{l}\text { Eliminating state } \\
\text { owned firms }\end{array}$ & $\begin{array}{c}\text { Eliminate } \\
\text { extreme } \\
\text { values }\end{array}$ & $\begin{array}{c}\text { 1998-2007 } \\
\text { Enterprise } \\
\text { sample }\end{array}$ & $\begin{array}{c}2008- \\
2013 \\
\text { Enterpris } \\
\text { e sample }\end{array}$ & $\begin{array}{c}\text { Controlling } \\
\text { the average } \\
\text { wage of } \\
\text { firms }\end{array}$ & $\begin{array}{l}\text { Control } \\
\text { province- } \\
\text { time effect }\end{array}$ \\
\hline \multirow[t]{2}{*}{ treatment $\times$ post } & $-0.0093 * *$ & $-0.0182 * * *$ & $-0.0229 * * *$ & $-0.003 * *$ & $-0.0139 * * *$ & $-0.027 * * *$ & $-0.0156 * * *$ & $-0.0575 * * *$ \\
\hline & $(-2.3563)$ & $(-6.6166)$ & $(-7.2030)$ & $(-2.5084)$ & $(-6.1947)$ & $(-4.8391)$ & $(-6.4045)$ & $(-8.7350)$ \\
\hline Control variable & Yes & Yes & Yes & Yes & Yes & Yes & Yes & Yes \\
\hline Time-fixed effect & Yes & Yes & Yes & Yes & Yes & Yes & Yes & Yes \\
\hline Region-fixed effect & Yes & Yes & Yes & Yes & Yes & Yes & Yes & Yes \\
\hline Province-time effect & No & No & No & No & No & No & No & Yes \\
\hline$N$ & 100623 & 577408 & 448230 & 324440 & 382799 & 194609 & 382380 & 577408 \\
\hline $\operatorname{adj} . R^{2}$ & 0.0912 & 0.1226 & 0.1215 & 0.2005 & 0.042 & 0.2124 & 0.0463 & 0.2531 \\
\hline
\end{tabular}

625 Notes: Control variables include size, age, soe, export, lntfp, lnkl, lngdp and urbanization. The

626 others are the same as in Table 2.

\section{4.4. Heterogeneity Test}

628 4.4.1. Industrial Pollution Intensity

629 Environmental legislation aims at dealing with pollution and protecting environment. However,

630 for the same regulation, heavy-pollution industries are greatly affected by legislation, while light- 

employment growth may vary across industries with different pollution level. In order to solve this problem, this paper first calculates the pollution intensity (pollut) of each industry, then constructs the interaction terms for pollution concentration with treatment variable and period variable respectively, and finally adds it into the benchmark model for triple DID estimation. In order to ensure the robustness of the regression results, in addition to retaining the numerical variable of industry pollution intensity, this paper also constructs dummy variables of industries with high or low pollution intensity based on the mean value of pollution intensity and divides the samples into two groups. Since there are many methods to calculate industrial pollution intensity and they are not unified and authoritative, this paper uses three methods to measure industrial pollution intensity. First, the emissions of industrial solid waste, waste gas and waste water per unit output value are treated the standardized emissions, then the emissions of these wastes are simply averaged to obtain the pollution degree index of the industry $i$ in the year $t$. Finally, the average pollution degree of industry $i$ is obtained by averaging the pollution degree from 1998 to 2013, which is the index of industry pollution intensity. Second, EPI index is constructed as a proxy index of industrial pollution intensity by $E P I=\sqrt{E \times P}$, where $E$ refers to the pollutant emission of per unit of industrial output value in the industry $i$ and the calculation method is similar to method 1 , and $P$ refers to the proportion of pollutant emission from industry $i$ in the total pollutant emission of all industries. Third, the coal consumption per unit of industrial output value is used as the proxy index of industrial pollution intensity.

The corresponding regression results are reported in Table 8. It can be seen that when the industrial pollution intensity is considered, environmental legislation still significantly reduces the employment growth of manufacturing firms. The coefficient of the triple interaction term is significantly negative. It indicates that compared with the industries with low pollution intensity, the inhibiting effect of environmental legislation on employment growth is more obvious in the industries with high pollution intensity. Table 8 . Heterogeneity test based on difference in industrial pollution intensity

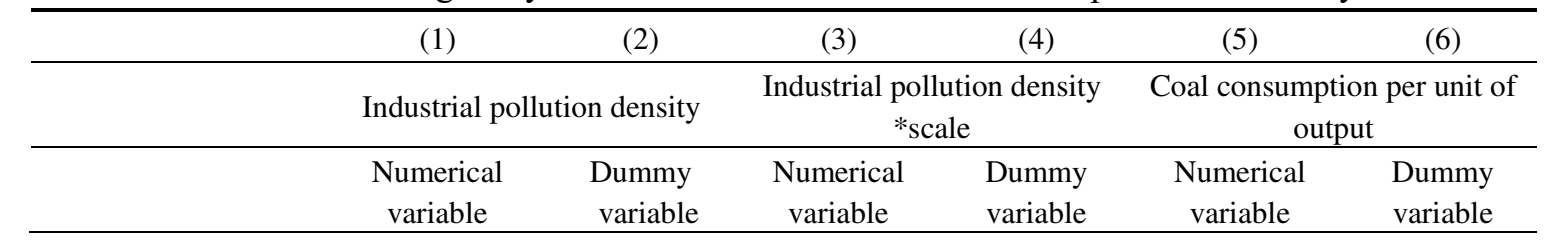




\begin{tabular}{ccccccc}
\hline treatment $\times$ post & $-0.0266 * * *$ & $-0.0262 * * *$ & $-0.0272 * * *$ & $-0.0222 * * *$ & $-0.0207 * * *$ & $-0.0230 * * *$ \\
& $(-19.1133)$ & $(-5.8709)$ & $(-19.3112)$ & $(-4.4823)$ & $(-6.6703)$ & $(-4.9411)$ \\
treat $\times$ post $\times$ pollut & $-0.0356 * *$ & $-0.0220 * * *$ & $-0.0094 * * *$ & $-0.0161 *$ & $-0.0023 * * *$ & $-0.0177 * *$ \\
& $(-2.5202)$ & $(-2.9147)$ & $(-2.5839)$ & $(-1.9970)$ & $(-2.9319)$ & $(-2.3282)$ \\
Control variables & Yes & Yes & Yes & Yes & Yes & Yes \\
Time-fixed effect & Yes & Yes & Yes & Yes & Yes & Yes \\
Region-fixed effect & Yes & Yes & Yes & Yes & Yes & Yes \\
\hline$N$ & 577259 & 577527 & 577259 & 577259 & 577259 & 577527 \\
adj. R2 & 0.1111 & 0.063 & 0.1112 & 0.0683 & 0.1111 & 0.0618 \\
\hline
\end{tabular}

Notes: Control variables include size, age, soe, export, lntfp, lnkl, lngdp and urbanization. The others are the same as in Table 2.

\subsubsection{Regional Enforcement Intensity}

The effect of environmental legislation depends on the degree of law enforcement, and the different intensity of enforcement has different impacts on the employment growth. In order to test how the effect of environmental legislation on employment growth varies with law's enforcement intensity, we use the number of environmental protection cases, the number of employees in the environmental protection departments and the number of institutions in the environmental protection system as the proxy variables of regional law enforcement intensity (case), respectively. It is used to construct interaction terms with treatment variable and period variable respectively. And these interaction terms are added into the benchmark model for triple DID estimation. As shown in Table 9, after controlling the intensity of regional environmental law enforcement, the coefficient of Treatment $\times$ Post is still significantly negative, indicating that environmental legislation significantly reduces the employment growth. The coefficient of the triple interaction term is negative, indicating that the restraining effect of environmental regulation on employment growth is more obvious in the areas with high enforcement intensity compared with the areas with weak enforcement intensity.

Table 9 . Heterogeneity test based on difference in regional enforcement intensity

\begin{tabular}{|c|c|c|c|c|c|c|}
\hline & (1) & $(2)$ & (3) & $(4)$ & $(5)$ & (6) \\
\hline & \multicolumn{2}{|c|}{ Environmental cases } & \multicolumn{2}{|c|}{$\begin{array}{l}\text { Number of employees in } \\
\text { environmental enforcement } \\
\text { departments }\end{array}$} & \multicolumn{2}{|c|}{$\begin{array}{c}\text { Number of institutions in } \\
\text { the environmental } \\
\text { protection system }\end{array}$} \\
\hline & $\begin{array}{c}\text { Numerical } \\
\text { variables }\end{array}$ & $\begin{array}{l}\text { Dummy } \\
\text { variable }\end{array}$ & $\begin{array}{c}\text { Numerical } \\
\text { variables }\end{array}$ & $\begin{array}{c}\text { Dummy } \\
\text { variable }\end{array}$ & $\begin{array}{c}\text { Numerical } \\
\text { variables }\end{array}$ & $\begin{array}{c}\text { Dummy } \\
\text { variable }\end{array}$ \\
\hline \multirow[t]{2}{*}{ treatment $\times$ post } & $-0.1334^{* * * *}$ & $-0.0059^{* *}$ & $-0.1832^{* * * *}$ & $-0.0110^{* * * *}$ & $-0.0609^{* * * *}$ & $-0.0057^{* *}$ \\
\hline & $(-10.446)$ & $(-2.2291)$ & $(-9.989)$ & $(-4.4550)$ & $(-5.118)$ & $(-2.4863)$ \\
\hline \multirow[t]{2}{*}{ treat $\times$ post $\times$ case } & $-0.0181^{* * *}$ & $-0.0150^{* * *}$ & $-0.0218^{* * *}$ & $-0.0228^{* * *}$ & $-0.0115^{* * *}$ & $-0.0210^{* * * *}$ \\
\hline & $(-9.9596)$ & $(-2.4549)$ & $(-9.7312)$ & $(-3.5817)$ & $(-5.5604)$ & $(-3.2775)$ \\
\hline Control variables & Yes & Yes & Yes & Yes & Yes & Yes \\
\hline Time-fixed effect & Yes & Yes & Yes & Yes & Yes & Yes \\
\hline
\end{tabular}




\begin{tabular}{ccccccc}
\hline Region-fixed effect & Yes & Yes & Yes & Yes & Yes & Yes \\
\hline$N$ & 573345 & 577408 & 577408 & 577408 & 569245 & 577408 \\
adj. $R^{2}$ & 0.1126 & 0.0726 & 0.1116 & 0.0673 & 0.1125 & 0.0725 \\
\hline
\end{tabular}

676

677

678

680

682

683

684

685

686

687

688

689

690

691

692

693

694

695

696

697

698

699

700

701

702

703

Notes: Control variables include size, age, soe, export, lntfp, lnkl, lngdp and urbanization. The others are the same as in Table 2.

\section{Further analysis based on job creation and job destruction}

In this part, we further divide a firm's employment growth into job destruction and job creation to analyze the impact of environmental legislation on employment growth in more details. When the local government implements certain environmental legislation, firms usually rent or buy pollution control equipment and use more environmentally friendly input to meet the new requirements. As a result, the firm's cost of production increases. Inevitably, the rapid rise of production costs in a short period will lead to the decline of the competitive advantage of firms, resulting in the reduction of the production scale and the demand for labor (Greenstone, 2002). The decrease in labor demand caused by environmental legislation is called job destruction effect in this paper. On the other hand, environmental legislation requires firms to increase investment on environmental protection. With the improvement on production equipment, the rate of return on capital factors also increases. According to Deschenes (2014), when the rate of return on capital factors increases, firms will reduce capital factor input and increase labor factor input with the substitution effect between capital factor and labor factor. In addition, "Porter Hypothesis" (Porter and Linde, 1995) points out that the well-designed environmental regulations force firms to increase investment on innovation. Moreover, the improved technology can reduce the marginal cost of production, increase the output scale of the firm, and finally increase the demand for labor. The phenomenon that environmental policies motivate firms to invest in innovation and increase employment is referred as job creation effect in this paper. Consequently, environmental legislation could have both job destruction and job creation effects, and the overall impact of environmental legislation on employment growth depends on the combined effect of job destruction and job creation.

The results of benchmark regression show the local environmental legislation significantly reduces employment growth of Chinese manufacturing firms. It can be inferred that there are three possible scenarios: (1) local environmental legislation increases job destruction while reducing job creation. (2) local environmental legislation increases job destruction and job creation, but the effect 

destruction and job creation, but the job destruction effect is smaller than the job creation effect. In order to test these conjectures and further characterize the employment redistribution effect, we also draw on the practices of Davis et al. (1996) and Groizard et al. (2015), defining three indicators of job creation, job destruction, and net employment growth respectively. Among them, employment creation is measured as: job_creation ${ }_{p f t}=\max \left(\Delta j o b s_{p f t}, 0\right), \Delta j o b s_{p f t}=j o b s_{p f t}-j o b s_{p f t-1} \cdot j o b s_{p f t}$ measured as: $j o b_{-}$destruction $n_{p f t}=\max \left(-\Delta j o b s_{p f t}, 0\right)$. Net employment growth is measured as: $j o b_{-} n e t_{p f t}=\Delta j o b s_{p f t}=j o b_{-}$creation $_{p f t}-j o b_{-}$destruction $_{p f t} \circ$ Table 10. Further analysis based on job creation and job destruction

\begin{tabular}{|c|c|c|c|c|c|c|}
\hline & (1) & (2) & (3) & (4) & (5) & (6) \\
\hline & $\begin{array}{c}\text { job_destructi } \\
\text { on }\end{array}$ & job_creation & job_net & job_destruction & job_creation & job_net \\
\hline & OLS & OLS & OLS & $\mathrm{FE}$ & FE & FE \\
\hline \multirow[t]{2}{*}{ treatment $\times$ post } & $0.0171^{* * * *}$ & $-0.0215^{* * * *}$ & $-0.038^{* * * *}$ & $0.0171^{* * * *}$ & $-0.0215^{* * * *}$ & $-0.0386^{* * *}$ \\
\hline & $(5.1475)$ & $(-6.8859)$ & $(-8.2503)$ & (11.1534) & $(-13.2246)$ & $(-15.9014)$ \\
\hline \multirow[t]{2}{*}{ size } & $-0.2212^{* * *}$ & $0.1242^{* * * *}$ & $0.3454^{* * *}$ & $-0.2212^{* * *}$ & $0.1242^{* * * *}$ & $0.3454^{* * *}$ \\
\hline & $(-46.8194)$ & $(24.4046)$ & (41.9409) & $(-103.1281)$ & (71.0173) & $(105.5502)$ \\
\hline \multirow[t]{2}{*}{ age } & $0.0001^{* * * *}$ & $-0.0001^{* * * *}$ & $-0.000^{* * * *}$ & $0.0001^{* * * *}$ & $-0.0001^{* * * *}$ & $-0.0001^{* * *}$ \\
\hline & $(5.6313)$ & $(-2.8485)$ & $(-4.4521)$ & $(5.8062)$ & $(-3.0302)$ & $(-4.9795)$ \\
\hline \multirow[t]{2}{*}{ soe } & $0.0231^{* * * *}$ & $-0.0408^{* * *}$ & $-0.064^{* * * *}$ & $0.0231^{* * * *}$ & $-0.0408^{* * * *}$ & $-0.0639^{* * * *}$ \\
\hline & $(5.9776)$ & $(-10.0912)$ & $(-8.8417)$ & (10.5273) & $(-19.4644)$ & $(-19.3772)$ \\
\hline \multirow[t]{2}{*}{ export } & $0.0161^{* * * *}$ & 0.0035 & $-0.0126^{* *}$ & $0.0161^{* * * *}$ & $0.0035^{*}$ & $-0.0126^{* * *}$ \\
\hline & $(4.6152)$ & $(0.9253)$ & $(-2.4402)$ & $(9.0873)$ & (1.7932) & $(-4.4589)$ \\
\hline \multirow[t]{2}{*}{$\operatorname{lntfp}$} & $0.6593^{* * * *}$ & $-0.4541^{* * * *}$ & $-1.113^{* * *}$ & $0.6593^{* * * *}$ & $-0.4541^{* * *}$ & $-1.1134^{* * *}$ \\
\hline & (28.7257) & $(-13.230)$ & $(-23.819)$ & (55.9905) & $(-49.8439)$ & $(-59.7417)$ \\
\hline \multirow[t]{2}{*}{$\operatorname{lnkl}$} & $0.1626^{* * * *}$ & $-0.0901^{* * * *}$ & $-0.252^{* * *}$ & $0.1626^{* * * *}$ & $-0.0901^{* * *}$ & $-0.2526^{* * *}$ \\
\hline & (37.6013) & $(-30.221)$ & $(-64.785)$ & (136.473) & $(-106.076)$ & $(-173.538)$ \\
\hline \multirow[t]{2}{*}{$\operatorname{lng} d p$} & $-0.1033^{* * *}$ & $-0.0553^{* * *}$ & $0.0480^{* * * *}$ & $-0.1033^{* * *}$ & $-0.0553^{* * *}$ & $0.0480^{* * * *}$ \\
\hline & $(-10.7978)$ & $(-4.8519)$ & (3.6308) & $(-27.3222)$ & $(-12.4680)$ & $(8.1788)$ \\
\hline \multirow[t]{2}{*}{ urbanization } & $0.2464^{* * * *}$ & $0.2376^{* * * *}$ & -0.0089 & $0.2464^{* * *}$ & $0.2376^{* * * *}$ & -0.0089 \\
\hline & $(6.3170)$ & $(3.3529)$ & $(-0.1073)$ & $(9.1215)$ & $(8.6051)$ & $(-0.2066)$ \\
\hline \multirow[t]{2}{*}{ Constant } & $1.5667^{* * *}$ & 0.1234 & $-1.443^{* * * *}$ & $1.5667^{* * *}$ & 0.1234 & $-1.4433^{* * *}$ \\
\hline & (13.5576) & $(1.2508)$ & $(-9.7676)$ & $(32.6632)$ & $(1.5643)$ & $(-16.0195)$ \\
\hline Time-fixed effect & Yes & Yes & Yes & Yes & Yes & Yes \\
\hline Firm-fixed effect & Yes & Yes & Yes & Yes & Yes & Yes \\
\hline Region-fixed effect & Yes & Yes & Yes & Yes & Yes & Yes \\
\hline$N$ & 577333 & 577333 & 577333 & 577333 & 577333 & 577333 \\
\hline $\operatorname{adj} . R^{2}$ & 0.3048 & 0.1923 & 0.2407 & 0.3026 & 0.1810 & 0.2690 \\
\hline
\end{tabular}


Note: $t$ values of the regression coefficient are in parentheses. $* * *, * *$, and $*$ refer to statistical significance at $1 \%, 5 \%$, and $10 \%$ respectively.

We use job_creation,job_destruction, and job_net as dependent variables, and then regressing Equation (1) by OLS model and fixed effect model respectively. The corresponding results are reported in Table 10. It can be seen that after controlling the time fixed effect, firms' individual fixed effect and regional fixed effect, local environmental legislation significantly improves the job destruction of manufacturing firms (Column (1) and (4)) and reduces the job creation (Column (2) and (5)). But the combination of the above two effects leads to a significant negative net employment growth effect, and the net employment growth of firms affected by environmental legislation is $3.86 \%$ lower than those not affected (Column (3) and (6)), which is similar to the benchmark regression. The result is consistent with scenario (2).

\section{Conclusions}

Based on the provincial data of environmental legislation and the data of Chinese manufacturing firms from 1998 to 2013, this paper studies the impact of local environmental legislation on the employment growth by using multiple methods. The results show that the environmental legislation significantly reduces the employment growth, and the three important channels are firm's entry and exit, export, and innovation. Besides, the results of heterogeneity analysis based on industrial pollution intensity and regional enforcement intensity show the documented effect of environmental legislation on employment growth is more obvious in the industries with high pollution intensity and in the areas with high enforcement intensity. Finally, the results of further analysis based on labor reallocation show that the local environmental legislation increases the job destruction and reduces the job creation, resulting in a significant negative influence on the net employment growth of the regulated manufacturing firms. This paper provides crucial policy implications on making effective environmental legislation. Effective environmental legislations should balance the improvement on ecological environment and high employment level. First, government's environmental policy should be flexible to ensure that the environmental standards in accordance with firm's characteristic to avoid "one size fits all". And flexible environment policies can not only achieve the purpose of reducing firms with high energy consumption, high pollution and low efficiency, but also avoid being too strict that firms choose to exit the market directly rather than invest on technological innovation. Secondly, this paper finds that environmental legislation has a negative impact on the employment growth via limiting their export decision. Therefore, the government should use multiple channels to stabilize export when implementing environmental legislation. For example, we can use fiscal policy to reduce the export risk of firms and provide financial support for export firms. Finally, this paper finds that technological R\&D and innovation serve as important channel that explains the impact of environmental legislation on firms' employment growth. Therefore, the government should provide 
more flexible environment for firm's $R \& D$ and innovation with appropriate fiscal policies and technical support. For example, government can build various forms of industry-university-research cooperation platforms and strengthen the public service system to achieve a reasonable allocation of scientific and technological innovation resources. Government also can take active measures to reduce fees and taxes and give special preferential treatment to $R \& D$ investment. In addition, government can improve the legal system for technological innovation to motivate more investment on R\&D. In sum, local environmental legislation, aimed at improving ecological and environmental quality, may have a negative impact on social welfare, while. Therefore, the government should take effective measures to limit the potential negative impacts, and balance "clear waters and green mountains" and "mountains of gold and silver".

760 


\section{Ethics declarations}

790 Ethics approval and consent to participate

791 Not applicable.

792

Consent for publication

794 Not applicable

795

\section{Competing interests}

797 The authors declare that they have no known competing financial interests or personal relationships 798 that could have appeared to influence the work reported in this paper.

799

800

\section{Authors Contributions}

801 Hongbing Li conceived the idea; Lei Wen and Xueying Bian organized the data and designed the

802 model; Lei Wen and Hongbing Li performed the data analysis and interpretation; Lei Wen and

803 Xueying Bian wrote the paper and provided feedback to all authors. All authors read and approved

804 the final manuscript.

805

806

\section{Funding}

807 The authors sincerely acknowledge three support funds. The first one is the National Social Science 808 Foundation of China (No.19FJLB023); the second one is the Natural Science Foundation of Beijing 809 (No.9192015); the third one is the Social Science Foundation of Beijing (No.20JJB010).

810

\section{Availability of data and materials}

812 The datasets and materials used and/or analyzed during the current study are available from the 813 corresponding author on reasonable request. 


\section{References}

Arimura T H. An empirical study of the SO2 allowance market: effects of PUC regulations [J]. Journal of Environmental Economics and Management, 2002, 44(2): 271-289.

Albrizio S, Kozluk T, Zipperer V. Environmental policies and productivity growth: Evidence across industries and firms [J]. Journal of Environmental Economics and Management, 2017, 81: 209-226.

Aldy, J. E. and W. A. Pizer. The Competitiveness Impacts of Climate Change Mitigation Policies [J]. Journal of the Association of Environmental and Resource Economists, 2015, 2 (4), 565-595.

Berman E, Bui L T M. Environmental regulation and labor demand: Evidence from the south coast air basin [J]. Journal of Public Economics, 2001, 79(2): 265-295.

Broner F, Bustos P, Carvalho V M. Sources of comparative advantage in polluting industries[R]. NBER Working Paper, no. 18337, 2012.

Becker R, Henderson V. Effects of air quality regulations on polluting industries [J]. Journal of political Economy, 2000, 108(2): 379-421.

Bailey J B, Thomas D W. Regulating away competition: The effect of regulation on entrepreneurship and employment [J]. Journal of Regulatory Economics, 2017, 52(3): 237-254.

Brandt L,Van Biesebroeck J,Zhang Y.Creative accounting or creative destruction? Firm-level productivity growth in Chinese manufacturing [J]. Journal of Development Economics, 2012, 97(2):339-351.

Costantini V, Crespi F. Environmental regulation and the export dynamics of energy technologies [J]. Ecological economics, 2008, 66(2-3): 447-460.

Cole M A, Elliott R J R. Do environmental regulations influence trade patterns? Testing old and new trade theories [J]. World Economy, 2003, 26(8): 1163-1186.

Cole, M.A., Elliott, R.J.R. and Shimamoto, K. Why the Grass Is Not Always Greener: The Competing Effects of Environmental Regulations and Factor Intensities on US Specialization [J]. Ecological Economics, 2005, 54(1):95-109.

Costantini, V. and Mazzanti, M. On the green and innovative side of trade competitiveness? The impact of environmental policies and innovation on EU exports[J].Research Policy,2012,41( 1):132-153.

Cai, X., Y. Lu, M. Wu, and L. Yu. Does Environmental Regulation Drive Away Inbound Foreign Direct Investment? Evidence from a Quasi-Natural Experiment in China [J]. Journal of Development Economics, 2016, (123):73-85.

Deschenes, O. Environmental regulations and labor markets [J]. IZA World of Labor, 2014.

Dauth W, Findeisen S, Suedekum J. The rise of the East and the Far East: German labor markets and trade integration [J]. Journal of the European Economic Association, 2014, 12(6): 1643-1675.

Davis S J, Haltiwanger J. Gross job creation, gross job destruction, and employment reallocation [J]. The Quarterly Journal of Economics, 1992, 107(3): 819-863.

Davis, S. J., J.C. Haltiwanger, and S. Schuh. Job Creation and Destruction[M]. The MIT Press, Cambridge, MA,1996.

Dooley, Michael P., David Folkerts-Landau and Peter Garber. An essay on the revived Bretton Woods System [J]. NBER Working Paper, no. 9971, 2003.

Dooley, Michael P., David Folkerts-Landau and Peter Garber. The revived Bretton Woods System: the effects of periphery intervention and reserve management on interest rates and exchange rates in center countries [J]. NBER Working Paper, no.10331, 2004.

Feenstra R C, Hong C, Dooley M. 5. China's exports and employment [M]. University of Chicago Press, 2010.

Greenstone, Michael. The Impacts of environmental regulations on industrial activity: evidence from the 1970 and 1977 Clean Air Act Amendments and the census of manufactures [J]. Journal of Political Economy, 
2002,110(6):1175 - 1219.

Groizard J L, Ranjan P, Rodriguez - Lopez A. Trade costs and job flows: Evidence from establishment - level data[J]. Economic Inquiry, 2015, 53(1): 173-204.

Gray, W. B. and R. J. Shadbegian. Do the job effects of regulation differ with the competitive environment? Does regulation kill Jobs? [M].2014, University of Pennsylvania Press.

Hall R E, Jones C I. Why do some countries produce so much more output per worker than others? [J]. the quarterly journal of economics, 1999, 114(1): 83-116.

Hummels D, Jorgensen R, Munch J, et al. The wage and employment effects of outsourcing: Evidence from Danish matched worker-firm data [J]. Working paper, Purdue University, 2010.

Head K, Ries J. Heterogeneity and the FDI versus export decision of Japanese manufacturers [J]. Journal of the Japanese \& International Economies, 2003, 17(4):448-467.

Hering, L. and Poncet, S. Environmental policy and exports: evidence from Chinese cities [J]. Journal of Environmental Economics and Management,2014,68(2):296-318.

Horbach J, Rennings K. Environmental innovation and employment dynamics in different technology fields: an analysis based on the German community innovation survey 2009[J]. Journal of Cleaner Production, 2013(57): $158-165$.

Jefferson G H, Tanaka S, Yin W. Environmental regulation and industrial performance: Evidence fro m unexpected externalities in China [J]. Available at SSRN 2216220, 2013. http:/cega.berkeley.edu/assets/ cega_events/49/Session_4C_Firm_Behavior.pdf.

Javorcik B S, Wei S J. Pollution havens and foreign direct investment: dirty secret or popular myth? [J]. NBER Working Paper, no. 8465, 2001.

Keller W, Levinson A. Pollution abatement costs and foreign direct investment inflows to US states [J]. Review of Economics and Statistics, 2002, 84(4): 691-703.

Kahn, M.E. and E.T.Mansur. Do local energy prices and regulation affect the geographic concentration of employment? [J]. Journal of Public Economics, 2013, 101 (C), 105-114.

Levinson A. Environmental regulations and manufacturers' location choices: Evidence from the Census of Manufactures [J]. Journal of public Economics, 1996, 62(1-2): 5-29.

Levinsohn J, Petrin A. Estimating production functions using inputs to control for unobservables [J]. The review of economic studies, 2003, 70(2): 317-341.

Liu M, Shadbegian R J, Zhang B, et al. Does environmental regulation affect labor demand in China? Evidence from the textile printing and dyeing industry [J]. Journal of Environmental Economics and Management, 2017: 277 294.

Liu M., Zhang, B., and Geng, Q. Corporate pollution control strategies and labor demand: evidence from China's Manufacturing Sector [J]. Journal of Regulatory Economics, 2018, 53(3), 298-326.

Marin, Giovanni; Vona, Francesco. The impact of energy prices on employment and environmental performance: evidence from French manufacturing establishments[J]. Working Paper, No. 053.2017, Fondazione Eni Enrico Mattei (FEEM), Milano, 2017.

Mani M, Wheeler D. In search of pollution havens? Dirty industry in the world economy, 1960 to 1995[J]. The Journal of Environment \& Development, 1998, 7(3): 215-247.

Naughton H T. To shut down or to shift: Multinationals and environmental regulation [J]. Ecological Economics, 2014, 102: 113-117.

Ohlin B. Interregional and International Trade [M]. Harvard University Press, Cambridge MA, 1933.

Olley, S. and Pakes, A. The dynamics of productivity in the telecommunications equipment industry [J]. Econometrica. 1996, 64(6):1263-1298. 
Porter M E and Van der Linde C. Toward a new conception of the environment-competitiveness relationship [J]. Journal of Economic Perspectives, 1995, 9(4):97-118.

Sen, A, Acharya, R. Environmental Standard and Employment: Impact of Productivity Effect [J]. Environment and Development Economics, 2012, 17(2): 207-225.

Stolper, W. F. and P. A. Samuelson. Protection and Real Wages[J]. The Review of Economic Studies, 1941,9(1): 58-73.

Shadbegian R G, Gray W B. Spatial patterns in regulatory enforcement: Local tests of environmental justice [R]. Washington, DC: NCEE Working Paper, 2009.

Tombe T, Winter J. Environmental policy and misallocation: The productivity effect of intensity standards [J]. Journal of Environmental Economics and Management, 2015, 72(7):137-163.

Wagner U J, Muûls M, Martin R, et al. The causal effects of the European Union Emissions Trading Scheme: evidence from French manufacturing plants[C]. Fifth World Congress of Environmental and Resources Economists, Istanbul, Turkey. 2014.

$\mathrm{Xu}, \mathrm{A}$. Environmental regulations and competitiveness: evidence based on Chinese firm data [J]. CIES research paper, No. 47, 2016.

Yang M, Yuan Y, Yang F, et al. Effects of environmental regulation on firm entry and exit and China's industrial productivity: a new perspective on the Porter Hypothesis [J]. Environmental Economics and Policy Studies, 2021: 1-30. 
Table 1. The results of two other parallel trend tests

\begin{tabular}{|c|c|c|}
\hline & $\begin{array}{l}\text { Two-phases before } \\
\text { and after legislation } \\
\text { (1) }\end{array}$ & $\begin{array}{l}\text { Multi-phases before } \\
\text { and after legislation } \\
\text { (2) }\end{array}$ \\
\hline & job_growth & job_growth \\
\hline \multirow[t]{2}{*}{ bef $\times$ treatment } & -0.0004 & \\
\hline & $(-0.1408)$ & \\
\hline \multirow[t]{2}{*}{ aft $\times$ treatment } & $-0.0183 * * *$ & \\
\hline & $(-6.2584)$ & \\
\hline \multirow[t]{2}{*}{ b_ $3 \times$ treatment } & & 0.0521 \\
\hline & & $(2.1669)$ \\
\hline \multirow[t]{2}{*}{ b_2 $2 \times$ treatment } & & 0.0052 \\
\hline & & $(1.3002)$ \\
\hline \multirow[t]{2}{*}{$b_{-} 1 \times$ treatment } & & -0.0023 \\
\hline & & $(-0.9031)$ \\
\hline \multirow[t]{2}{*}{ cur $\times$ treatment } & & $-0.0066^{* *}$ \\
\hline & & $(-2.1338)$ \\
\hline \multirow[t]{2}{*}{ a_l $1 \times$ treatment } & & $-0.0193 * * *$ \\
\hline & & $(-6.6942)$ \\
\hline \multirow[t]{2}{*}{ a_ $2 \times$ treatment } & & $-0.0296 * * *$ \\
\hline & & $(-7.4005)$ \\
\hline \multirow[t]{2}{*}{ a_ $3 \times$ treatment } & & $-0.0209 * * *$ \\
\hline & & $(-3.1309)$ \\
\hline Control variable & Yes & Yes \\
\hline Time-fixed effect & Yes & Yes \\
\hline Region-fixed effect & Yes & Yes \\
\hline $\mathrm{N}$ & 577408 & 577408 \\
\hline adj. R2 & 0.1226 & 0.1228 \\
\hline
\end{tabular}

949 Note: Control variables include size, age, soe, export, lntfp, lnkl, lngdp and urbanization. $t$ values

950 of the regression coefficient are in parentheses. ***, **, and * refer to statistical significance at $1 \%$, $9515 \%$, and $10 \%$ respectively. 